\title{
SEED BANK VIABILITY IN JACKSON LAKE Grand Teton National PARK, Wyoming
}

\author{
CAROL A. BREWER $\downarrow$ MELISSA BROWN \\ DIVISION OF BIOLOGICAL SCIENCES $\downarrow$ THE UNIVERSITY OF MONTANA \\ MISSOULA
}

\begin{abstract}
$\downarrow \quad$ INTRODUCTION
The submersed plant community in Jackson Lake is an important resource in Grand Teton National Park for both terrestrial and aquatic organisms. Since the early 1900's, Jackson Lake has been influenced by a series of drawdowns of varying magnitude that influenced the composition and extent of the macrophyte community in the littoral zone. While many physical conditions have been linked to macrophyte growth and distribution in lakes (e.g., light, sediments, nutrients, slope) recent work suggests that the magnitude and timing of water level fluctuations may be the most important factor regulating macrophyte community processes at shallower depths in regulated reservoirs (Brewer and Parker 1990; Gasith and Gafny 1990; Rørslett 1984, 1987).
\end{abstract}

Because of the importance of the aquatic plant community in Jackson Lake as a food source and shelter for wildlife (waterfowl, fish, invertebrates, mammals), the factors affecting growth and recovery after disturbance have received periodic attention since the late 1960's (Hayden 1969; Brewer 1986; Brewer and Rørslett 1987; Brewer and Parker 1990; Brewer and Thompson 1994). Initial work on plant community dynamics in Jackson Lake has shown that the aquatic plant community in Jackson Lake has been exposed to a varied disturbance regime that has impacted recolonization, species diversity and peak biomass development. Because the extent of littoral habitat suitable for macrophyte growth in regulated lakes depends on the timing and magnitude of seasonal and long-term drawdowns, drawdown schedules and resulting fluctuating water levels may be selecting for a plant community characterized by low diversity and patchy distribution. Peak production under such conditions in Jackson Lake tends to be shifted into deeper waters (Brewer and Parker 1990; Brewer and Thompson 1994). Furthermore, clonal, weedy species with reduced value for wildlife (e.g., Elodea canadensis, Myriophyllum sibericum) have enhanced opportunities for dispersal under such a disturbance regime and are favored when maximum drawdown occurs during the period of peak standing crop.

While historical records describing changing patterns of macrophyte distribution are available for Jackson Lake, few data are available to evaluate the influence of fluctuating water levels on the seed bed, and the potential for recruitment after disturbance from this source. The objective for our work was to establish protocols and collect preliminary data on the potential for recruiting macrophytes from the littoral seed bank by measuring germination of seeds from lake sediments. 


\section{$\downarrow$ METHODS}

\section{SEDIMENT COLLECTION}

Lake bed sediments were collected from shallow shelf and sheltered bay habitats in the area of Third Creek drainage. This site was chosen based on previous data on macrophyte diversity. Using an Ekman dredge, muds were collected from four depth intervals $(0-2 \mathrm{~m}, 2-4 \mathrm{~m}, 4-6 \mathrm{~m}$, and $6-8 \mathrm{~m})$ along two transect lines. After collection, samples were carefully filtered (to avoid loss of seeds) through coarse screen to remove excess water and organic debris. Samples were placed in labeled containers for storage.

Samples for measuring germination were prepared separately for each transect at each depth interval. Each separate sample was mixed well and large pebbles and plant material were removed by sieving through a large bore screen. The sample was then allowed to settle so that excess water could be decanted off. All decanting was done through a fine sieve to avoid seed loss. Each composite sample was subdivided, and transferred to 1 gallon Ziplock baggies for cool storage.

\section{EXPERIMENTAL DESIGN}

A flow-through aquatic system equipped with both inflow and outflow pipes was set up to simulate germination at three different depths and at fluctuating water levels. Separate tanks were used for each depth $(10,20$ and $30 \mathrm{~cm}$ deep), and for the fluctuating water level treatment $(10-30 \mathrm{~cm})$. Once samples were in place, screens were placed over each tank to avoid litter fall.

Containers $(30 \times 10 \times 10 \mathrm{~cm})$ were prepared for planting by dividing them into two sections $(15 \times 10 \times 10 \mathrm{~cm})$. Each subsection was first filled with $750 \mathrm{~cm}^{3}$ of peat moss; then, each received $250 \mathrm{~cm}^{3}$ of lake sediment. Thus, each planting container contained replicate samples from each depth class (one from each original transect). Four planting containers (representing the four collection depths of $0-2 \mathrm{~m}, 2-4 \mathrm{~m}, 4-6 \mathrm{~m}$, and $6-8 \mathrm{~m}$ ) were placed in each experimental tank. Control containers contained only $750 \mathrm{~cm}^{3}$ of peat moss. The containers were submersed very slowly into the tanks to avoid disturbing the sediments and mixing the samples. Once a week for the duration of the experiment, the water level in the drawdown tank was lowered by $5 \mathrm{~cm}$. Water levels were maintained at constant levels in the remaining three tanks. Data on water level, water temperature, and seedling emergence (number and type/species) were recorded 2 - 3 times per week. Once per week, containers with sediment samples were rotated to minimize any affects associated with position in the tank.

\section{SEEDLING COUNTS}

Planting containers were removed individually from each tank to count seedlings. As seedlings emerged, they were marked with a colored tooth pick and numbered flag. When they were large enough for identification, seedlings were removed. Every other week, the sediment was tilled to bring new seeds to the surface and break up any algal crusts on the surface.

\section{$\downarrow \quad$ RESULTS AND DISCUSSION}

For the duration of the experiments, no seedlings emerged from the control containers. Very few seedlings were germinated from sediments collected from depths of less than $4 \mathrm{~m}$ (Table 1). It is likely that most of the seeds falling into such shallow waters were terrestrial in origin. The greatest germination occurred from samples collected at depths greater than $6 \mathrm{~m}$ from the Third Creek area. By late August and early September, much of the region covered by shallow water in June and July was dewatered due to drawdown. Thus, seeds maturing during these months tend to fall and accumulate in deeper water.

Table 1. Germination during July 12 - August 5, 1997 of aquatic macrophyte seedlings collected from 4 depth classes in Jackson Lake.

\begin{tabular}{ll}
\hline \hline Depth of Sediment & Total \# of Seedlings \\
Collection & Germinated
\end{tabular}

0-2 m

157

$2-4 \mathrm{~m} \quad 51$

$4-6 m \quad 547$

$6-8 \mathrm{~m} \quad 1142$

In general, there was little difference in the number of seedlings germinating as a function of 
water depth during our experiments (Table 2). This result is somewhat surprising. We expected germination rates to be lowest in the treatment with only $10 \mathrm{~cm}$ of water. It is possible that some of the seedlings that germinated were terrestrial plants, thus artificially inflating our germination results. Further analysis is underway on these data.

Table 2. Germination of aquatic macrophyte seedlings as a function of depth of water during July 12 - August 5, 1997.

\begin{tabular}{ll}
\hline \hline $\begin{array}{ll}\text { Depth during } \\
\text { Germination }\end{array}$ & $\begin{array}{l}\text { Total \# of Seedlings } \\
\text { Germinated }\end{array}$ \\
\hline Fluctuating & 479 \\
$10 \mathrm{~cm}$ & 499 \\
$20 \mathrm{~cm}$ & 445 \\
$30 \mathrm{~cm}$ & 474 \\
\hline
\end{tabular}

During the germination experiment, seedlings from 10 species germinated (Table 3). Seedlings of Sparganium sp. were most common. This genera is typical of marsh habitats and is usually emergent in shallow water. Limnosella aquatica, an amphibious annual, and Eleocharis acicularis, a perennial emergent species, also were very well represented in the seed bank near Third Creek. The truly submergent macrophytes (Elodea canadensis, Potamogeton pectinatus, and Potamogeton pusillus) were not abundant in the seed bank, though they are some of the most common macrophytes in the lake. This suggests they may reproduce more commonly through vegetative means, and the seed bank is not as important for recruitment.

\section{RECOMMENDATIONS FOR FUTURE STUDIES}

The preliminary data collected during this study suggest that the seed bank in the southeastern portion Jackson lake may play a relatively small role in macrophyte recruitment compared to recruitment from vegetative tissues (e.g., rhizomes, turions, roots, stem fragments). Data from other habitat types and locations in Jackson Lake are needed to develop a more complete understanding of recruitment patterns from the seed bank.
Table 3. Number of macrophyte seedlings germinated from seeds from July 12 - August 22, 1997.

\begin{tabular}{lr}
\hline \hline Species & \# seedlings \\
\hline Eleocharis acicularis (1.)R.\&.S. & 91 \\
Elodea canadensis Michx. & 6 \\
Limnosella aquatica L. & 191 \\
Sparganium sp. & 1819 \\
Potamogeton pectinatus L. & 11 \\
Potamogeton pusillus L. & 61 \\
Unknown 1 & 148 \\
Unknown 2 & 216 \\
Unknown 3 & 115 \\
Unknown 4 & 187 \\
\hline
\end{tabular}

Building on the historical data available for macrophyte distribution, the following areas deserve future consideration as we begin to evaluate trophic linkages in this system: 1) patterns of macrophyte community development, 2) community productivity in terms of growth, photosynthesis, and seasonal biomass production, 3) niche dynamics in light of an unpredictable disturbance regime related to water level drawdowns, 4) differential responses of plants propagating by fragmentation versus seeds under different disturbance regimes; and 5) trophic and nutrient linkages between the aquatic macrophyte community and consumers in the greater lake ecosystem.

\section{ACKNOWLEDGMENTS}

This study was funded by the UW-NPS Research Center and the National Park Service. We thank the staff at the UW-NPS Research Center for assisting with all aspects of the field work.

\section{LITERATURE CITED}

Brewer, C.A. 1986. An investigation of the aquatic macrophyte community in Jackson Lake, Wyoming: distribution, effect of moving water and species-specific tensile properties. Masters Thesis, Department of Zoology and Physiology, University of Wyoming, Laramie, WY. 
Brewer, C. A. and M. Parker. 1990. Adaptations of macrophytes to life in moving water: upslope limits and mechanical properties of stems. Hydrobiologia 194:133-142.

Brewer, C. A. and B. Rørslett. 1987. Norwegian macrophyte models applied to an American reservoir. In B. Bretten and O. I. Ronning (eds.), Symposium in vegetation ecology at Kongsvold Biological Station in March 1987. Universitetet I Trondheim, Vitenskapsmuseet Rapport Botanisk Serie 1987 1:7-17.

Brewer, C.A. and T.G. Thompson. 1994. The aquatic plant community in Jackson Lake, Grand Teton National Park: dynamics of a disturbed system. In, D. Despain (ed.), Plants and Their Environments-1st Biennial Scientific Conference on the Greater Yellowstone Ecosystem. National Park Service Transaction Series.
Gasith, A. and S. Gafny. 1990. Effect of water level fluctuation on the structure and function of the littoral zone. In M. M. Tilzer and C. Serruya (eds.), Large Lakes: Ecological Structure and Function. Springer-Verlag. Berlin. pp 156-171.

Hayden, P.S. 1969. Jackson Lake limnological investigations. National Park Service Progress Report 1968-1969 (unpublished).

Rørslett, B. 1984. Environmental factors and aquatic macrophyte response in regulated lakes - a statistical approach. Aquatic Botany 19:199-220.

Rørslett, B. 1987. Niche statistics of submerged macrophytes in Tyrifjord, a large oligotrophic Norwegian lake. Archiv Hydrobiologia 111:283-308. 